\title{
KAJIAN PELAKSANAAN PROGRAM PEMBERDAYAAN MASYARAKAT PESISIR BERBASIS PENGELOLAAN BERKELANJUTAN PADA BUDIDAYA BANDENG DI PESISIR KABUPATEN KARAWANG
}

\section{Implementation Study of The Coastal Communities Empowerment Program Based on Sustainable Management of Milkfish Cultured In The Coastal Regency of Karawang}

\author{
"Dicky Rachmanzah', Bambang Widigdo² dan Yusli Wardiatno² \\ ${ }^{1}$ Mahasiswa Program Studi Pengelolaan Pesisir dan Lautan, Sekolah Pascasarjana, IPB. \\ ${ }^{2}$ Dosen pada Departemen MSP, FPIK-IPB \\ "email: rachmanzahdicky@gmail.com
}

Diterima 20 November 2013 - Disetujui 6 Juni 2014

\begin{abstract}
ABSTRAK
Penelitian ini bertujuan untuk: (1) menilai kesesuaian pelaksanaan dan capaian tujuan program penberdayaan melalui penilaian Indeks Pelaksanaan Program dan Indeks Pencapaian Tujuan; (2) mengidentifikasi pengaruh variabel pelaksanaan sebagaimana disebutkan dalam pedoman pemberdayaan terhadap tujuan program pemberdayaan dalam dimensi ekologis, ekonomi, dan sosial, serta; (3) merumuskan strategi perbaikan yang perlu dilakukan sehingga pelaksanaan program pemberdayaan masyarakat pesisir dapat terlaksana dan berlanjut secara efektif. Metode penelitian yang digunakan adalah metode survey. Hasil penelitian menunjukkan bahwa: (1) Indeks Pelaksanaan Program adalah sebesar 2,39 dengan kategori 'Baik'. Indikator yang memerlukan upaya perbaikan yaitu indikator ketepatan waktu penyaluran bantuan; (2) Indeks Pencapaian Tujuan sebesar 2,11 dengan kategori Cukup. Indikator capaian tujuan peningkatan kualitas lingkungan dan peningkatan kelembagaan kelompok memerlukan upaya perbaikan guna pencapaian kategori yang lebih baik; (3) Terhadap pencapaian tujuan dalam dimensi ekonomi berupa peningkatan produksi budidaya, variabel ketepatan waktu penyaluran, kecukupan jumlah bantuan, dan aktivitas pendampingan berpengaruh positif, sedangkan variabel kejadian kekeringan berpengaruh negatif; (4) Untuk pencapaian tujuan dalam dimensi sosial, hanya variabel aktivitas pendampingan yang berpengaruh signifikan terhadap peningkatan kelembagaan kelompok, dan; (5) Keseluruhan variabel pelaksanaan tidak berpengaruh terhadap capaian tujuan dalam dimensi ekologis berupa peningkatan kualitas lingkungan. Dengan memperhatikan hasil analisis, beberapa opsi kebijakan yang perlu dilakukan oleh Kementerian Kelautan dan Perikanan yaitu: (1) penyesuaian waktu penyaluran bantuan dengan musim tanam untuk meningkatkan efektifitas capaian tujuan dalam dimensi ekonomi; (2) peningkatan dukungan terhadap aktivitas pendampingan oleh tenaga penyuluh, untuk meningkatkan capaian tujuan dalam dimensi sosial, dan; (3) peningkatkan capaian tujuan dalam dimensi ekologis, berupa peningkatan kualitas lingkungan melalui pemberian intensif bagi pembudidaya yang memiliki sertifikat cara budidaya ikan yang baik (CBIB).
\end{abstract}

Kata Kunci: pemberdayaan, budidaya, Karawang, bandeng, indeks pelaksanaan program, indeks pencapaian tujuan

\footnotetext{
ABSTRACT

This study aimed to: (1) assess the suitability of the empowerment program implementation and goals through the introduction of programs implementation Indexes and achievement of goals indexes; (2) identify influences of enforcement variable mentioned in empowerment guidelines against goals of empowerment programs, the objectives in the form of economic, social, and ecology dimensions, and; (3) formulate strategy that needs to be done so the program can continue and be implemented effectively in achieving its goal. Survey was used as the research method. The result of studies have shown that: (1) Program Implementation Index that states performance level of coastal community empowerment program is worth 2.39 with the Good category. Performance indicators that require improvement efforts in order to achieve a better category, i.e. punctuality indicators of aid distribution; (2) Achievement Index that states the level of achievement goals of empowerment program is worth 2.11 with moderate
} 
categories. The whole purpose of indicators that include increased production, increased institutional farmer group, and improving the quality of the environment in the category of quite and require attention and improvement efforts in order to achieve a better category; (3) against the objectives in the form of economic, variable aid delivery timeliness, adequacy of the amount of aid, and mentoring activity has a positive effect, while the incidence of drought has negative impact; (4) against the objectives in the form of social, only mentoring activities has a positive effect, and; (5) all of implementation variable hasn't effect against the objectives in the form of ecology. By considering the results of the analysis, some policy options that need to be done by Ministry of Marine Affairs and Fisheries are: 1) timing adjustment aid to the fish cultivation to increase the effectiveness of objectives in the form of economic; (2) Improved support for mentoring activities, to increase the objectives in the form of social; (3) and improvement of objectives in the form of ecology objectives through the provision of intensive to the farmers who are certified best aquaculture practiced.

\section{Keywords: empowerment, aquaculture, Karawang, milkfish, program implementation index, achievement index}

\section{PENDAHULUAN}

Kondisi pembudidaya yang berada di pesisir Kabupaten Karawang, hingga saat ini masih belum memenuhi harapan, baik dalam aspek ekonomi, sosial, maupun lingkungan. Dari aspek ekonomi, hasil penelitian Karim (2005) menunjukkan bahwa Indeks Kemiskinan Manusia di Kabupaten Karawang pada tahun 2002 yaitu sebesar $29,8 \%$, dengan ketertinggalan dalam faktor kesehatan masyarakat. Dari aspek sosial, perkembangan kelembagaan ekonomi lebih berorientasi untung rugi dan menguntungkan juragan sebagai pemilik sumberdaya dibandingkan buruh. Begitu pula dari aspek lingkungan, hasil perhitungan menggunakan Indeks Mutu Lingkungan Perairan (IMLP) yang dikembangkan oleh US-National Sanitation Foundation menunjukkan bahwa status kualitas perairan di wilayah pesisir utara Karawang berkisar antara 58,71 sampai dengan 67,78 dari skala 1 sampai dengan 100 (Suriadarma, 2011). Hasil perhitungan tersebut jika dibandingkan dengan kriteria mutu lingkungan perairan menurut NSF-WQI (Qtt, 1978) berada dalam kualifikasi sedang mendekati buruk untuk memelihara organisme perairan seperti ikan atau udang. Namun, kondisi tersebut bukan disebabkan kelemahan pembudidaya semata, tetapi terkadang hal itu terjadi di luar kendali mereka. Biasanya, karena kebijakan yang buruk dari institusi negara atau masyarakat yang tidak memperhatikan mereka (World Bank, 2001 dalam Mulyanto, 2012).

Untuk meningkatkan kondisi ekonomi dan sosial pembudidaya, serta meningkatkan kualitas lingkungan, pemerintah telah menginisiasi upaya pemberdayaan masyarakat melalui pelaksanaan program pemberdayaan masyarakat pesisir berbasis pengelolaan berkelanjutan. Saat ini di
Kabupaten Karawang, telah diimplementasikan program pemberdayaan masyarakat pesisir berbasis pengelolaan berkelanjutan, yaitu melalui kegiatan Pengembangan Usaha Mina PedesaanPerikanan Budidaya (PUMP-PB) sebagai bagian dari Program Nasional Pemberdayaan Masyarakat Mandiri-Kelautan dan Perikanan (PNPM Mandiri KP), serta melalui program Pengembangan Perikanan Budidaya Berkelanjutan untuk Ketahanan Pangan dan Pengurangan Kemiskinan atau Suistanable Aquaculture Development for Food Security and Poverty Reduction (Safver) project.

Selanjutnya, agar program pemberdayaan masyarakat di pesisir Kabupaten Karawang berlanjut dan terlaksana secara efektif dalam mencapai tujuannya, maka diperlukan suatu kajian mengenai program pemberdayaan masyarakat pesisir berbasis pengelolaan berkelanjutan. Penelitian ini bertujuan untuk: 1) menilai kesesuaian pelaksanaan dan capaian tujuan program pemberdayaan melalui penilaian Indeks Pelaksanaan Program dan Indeks Pencapaian Tujuan, 2) mengidentifikasi pengaruh variabel pelaksanaan sebagaimana disebutkan dalam pedoman pemberdayaan terhadap pencapaian tujuan program pemberdayaan dalam dimensi ekonomi, sosial dan ekologis, serta 3) merumuskan strategi perbaikan yang perlu dilakukan sehingga pelaksanaan program pemberdayaan masyarakat pesisir dapat terlaksana dan berlanjut secara efektif.

\section{METODOLOGI}

\section{Lokasi dan Waktu Penelitian}

Penelitian dilaksanakan selama empat bulan, yaitu pada bulan April sampai dengan Juli 2013. Pengambilan data dilakukan di dua kecamatan 
pesisir pada Kabupaten Karawang yang telah menerima bantuan program pemberdayaan masyarakat, yaitu: Kecamatan Tirtajaya dan Kecamatan Cilamaya Wetan.

\section{Metode Penelitian}

Pengumpulan data dan informasi dilakukan dengan melakukan desk study dan survai lapangan. Desk study dilakukan dengan membuat kompilasi dan sintesa data sekunder (data statistik, hasil penelitian, dan dokumen kebijakan lainnya). Sedangkan survai lapangan berupa pengumpulan data primermelalui wawancara dengan berpedoman pada kuesioner. Secara umum, tahapan proses analisis dalam penelitian ini mencakup hal-hal sebagai berikut:

1. Penetapan variabel dan skala penilaian kesesuaian pelaksanaan dan pencapaian tujuan program

Berdasar pada pedoman program pemberdayaan berupa Pedoman Teknis PUMP-PB (Ditjen Perikanan Budidaya, 2012), dan Pedoman Pemberian InputProduksikepada Pembudidayalkan
Penerima Manfaat Proyek Safver (Ditjen Perikanan Budidaya, 2009), kesesuaian pelaksanaan dinilai berdasarkan enam variabel pelaksanaan, meliputi: lama pengalaman pembudidaya, kejadian kekeringan, aksesibilitas/jarak pembelian benih, ketepatan waktu penyaluran, kecukupan jumlah bantuan, dan aktivitas pendampingan. Sedangkan capaian tujuan dinilai berdasarkan tiga variabel tujuan, yaitu tujuan dalam dimensi ekonomi berupa peningkatan produksi budidaya, dalam dimensi sosial berupa peningkatan kelembagaan (kelas) kelompok, dan dalam dimensi ekologis berupa peningkatan kualitas lingkungan, sebagaimana pada Tabel 1.

\section{Penyusunan dan pendistribusian kuesioner}

Selanjutnya, guna memperoleh informasi yang dibutuhkan, disusun kuesioner penelitian. Responden kuesioner penelitian dipilih secara sengaja (purposive sampling), yaitu ditetapkan sebanyak 110 pembudidaya bandeng penerima program pemberdayaan (meliputi program PUMP-PB dan Safver) yang berada di Kecamatan Tirtajaya dan Cilamaya Wetan Kabupaten Karawang, dari jumlah keseluruhan penerima

Tabel 1. Variabel dan Skala Penilaian.

Table 1. Variable and Valuation Scale.

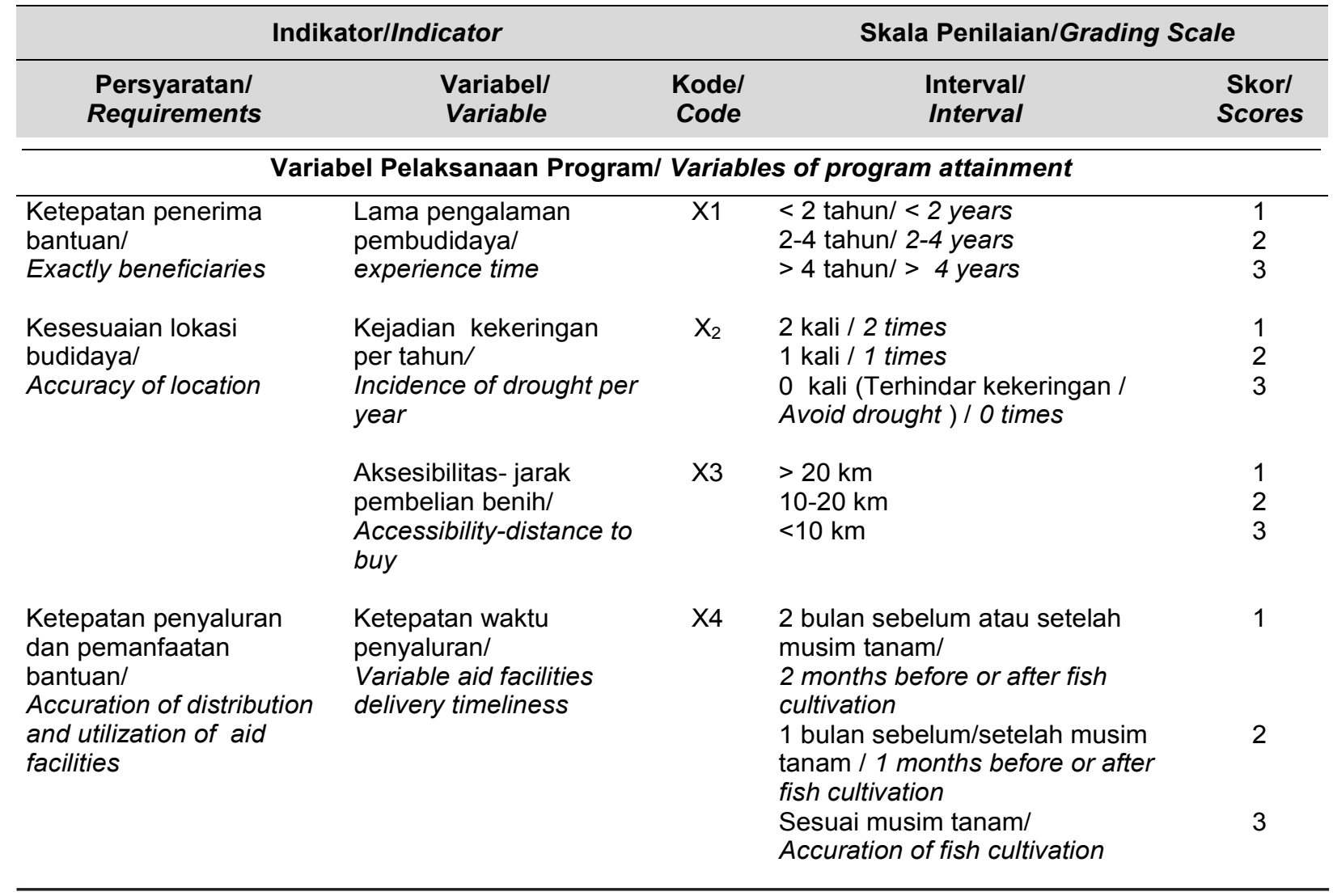


Lanjutan Tabel 1/Continues Table 1

\begin{tabular}{ccccc}
\hline \multicolumn{2}{c}{ Indikator/Indicator } & \multicolumn{2}{c}{ Skala Penilaian/Grading Scale } \\
\hline $\begin{array}{cccc}\text { Persyaratan/ } \\
\text { Requirements }\end{array}$ & Variabel/ & Kodel & Interval/ & Skorl \\
& Variable & Code & Interval & Scores \\
\hline & Variabel Pelaksanaan Program/ Variables of program attainment
\end{tabular}

Variabel Pelaksanaan Program/ Variables of program attainment

\begin{tabular}{|c|c|c|c|c|}
\hline & $\begin{array}{l}\text { Kecukupan jumlah } \\
\text { bantuan benih/ } \\
\text { Adequacy of the } \\
\text { amount of aid facilities }\end{array}$ & $\times 5$ & $\begin{array}{l}\text { dibandingkan jumlah benih yang } \\
\text { biasa ditebar / Ratio of juvenile } \\
\text { stocked before and after aid } \\
\text { facilities: } \\
<90 \% \\
90-110 \% \\
>110 \%\end{array}$ & $\begin{array}{l}1 \\
2 \\
3\end{array}$ \\
\hline \multirow[t]{3}{*}{$\begin{array}{l}\text { Efektivitas } \\
\text { pendampingan/ } \\
\text { Efectivity of mentoring }\end{array}$} & $\begin{array}{l}\text { Aktivitas } \\
\text { pendampingan/ } \\
\text { Mentoring activity }\end{array}$ & X6 & $\begin{array}{l}\text { Mencakup } 1 \text { diantara } 3 \text { kegiatan } \\
\text { pendampingan**/ } \\
\text { Including } 1 \text { of } 3 \text { mentoring } \\
\text { activities }\end{array}$ & 1 \\
\hline & & & $\begin{array}{l}\text { Mencakup } 2 \text { diantara } 3 \text { kegiatan/ } \\
\text { Including } 2 \text { of } 3 \text { mentoring } \\
\text { activities }\end{array}$ & 2 \\
\hline & & & $\begin{array}{l}\text { Mencakup keseluruhan } 3 \\
\text { kegiatan/ } \\
\text { Including } 3 \text { mentoring activities }\end{array}$ & 3 \\
\hline
\end{tabular}

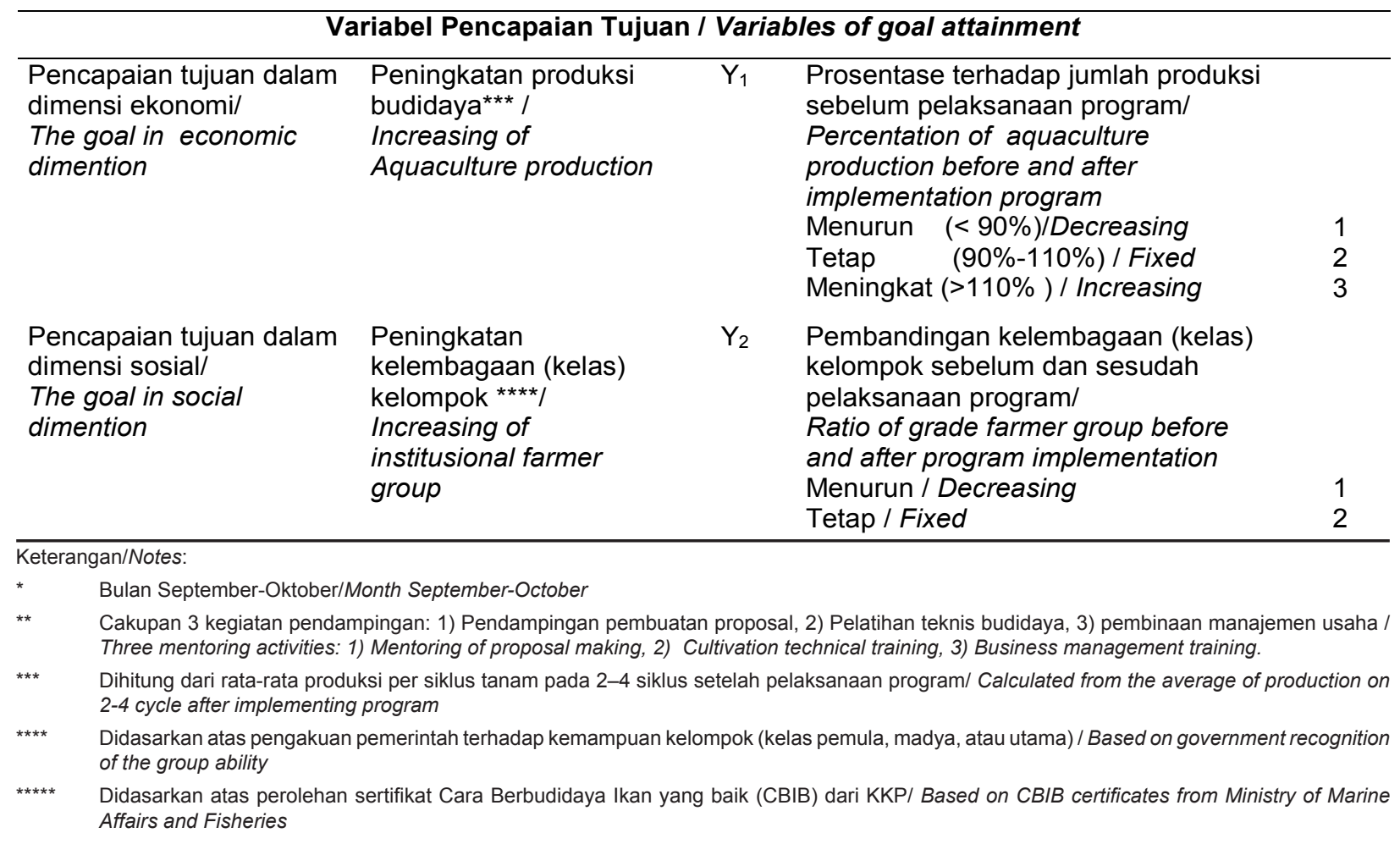

bantuan sebanyak 313 orang, sebagaimana pada Lampiran 1. Penentuan jumlah sampel ini telah memenuhi ukuran keterwakilan, dikarenakan mengacu pada rumus Slovin dengan tingkat kepercayaan $90 \%$ atau taraf signifikansi 0,10 , jumlah sampel yang dipersyaratkan adalah minimal 76 orang, sebagaimana pada Lampiran 2.
3. Penilaian atas kesesuaian pelaksanaan dan capaian tujuan program pemberdayaan

Berdasarkan hasil kuesioner dilakukan pengelompokkan atas masing-masing variabel pelaksanaan dan variabel tujuan berdasarkan interval skala penilaian yang ada pada Tabel 1, sehingga didapat total nilai skor dari masing- 
masing variabel. Capaian setiap variabel diperoleh dengan membagi total nilai skor dengan jumlah responden. Selanjutnya, nilai capaian keseluruhan variabel, dirata-ratakan untuk menghitung tingkat kesesuaian pelaksanaan program berdasarkan nilai Indeks Pelaksanaan Program, dan tingkat keberhasilan pencapaian tujuan program pemberdayaan berdasarkan Indeks Pencapaian Tujuan, atau dihitung berdasarkan rumus: Indeks $=\Sigma$ capaian variabel $/$ jumlah variabel. Nilai variabel dan indeks dengan selang nilai 1-3, terbagi atas lima kategori, yaitu: sangat buruk, buruk, cukup, baik dan sangat baik, sebagaimana terdapat pada Tabel 2.

\section{Pengidentifikasian pengaruh variabel pelaksanaan terhadap capaian tujuan program}

Analisis ini mengidentifikasi pengaruh enam variabel pelaksanaan program pemberdayaan yang meliputi: lama pengalaman pembudidaya $\left(X_{1}\right)$, kejadian kekeringan $\left(X_{2}\right)$, aksesibilitas/jarak pembelian benih $\left(X_{3}\right)$, ketepatan waktu penyaluran $\left(X_{4}\right)$, kecukupan jumlah bantuan $\left(X_{5}\right)$, dan aktivitas pendampingan $\left(X_{6}\right)$ terhadap variabel tujuan dalam dimensi ekonomi $\left(Y_{1}\right)$, dimensi sosial $\left(Y_{2}\right)$, dan dimensi ekologis $\left(\mathrm{Y}_{3}\right)$.

a. Terhadap tujuan dalam dimensi ekonomi berupa peningkatan produksi budidaya $\left(Y_{1}\right)$

Variabel $X$ dan variabel $Y_{1}$ berbentuk skala rasio, sehingga statistik parametrik analisis regresi linear berganda (multiple regression) merupakan teknik analisis yang tepat digunakan (Latan \& Temalagi, 2013), setelah terlebih dahulu dilakukan pengujian terhadap asumsi regresi linear berupa uji normalitas, uji multikolinearitas, dan uji heteroskedastisitas untuk menghindari munculnya bias dan kesalahan spesifikasi model regresi yang digunakan. Hasil analisis atas pengujian asumsi menunjukkan bahwa model regresi yang digunakan sudah baik, yaitu terlihat dari data terdistribusi normal secara multivariat, tidak terdapat problem multikolonieritas, dan tidak terjadi permasalahan heteroskedastisitas.

b. Terhadap tujuan dalam dimensi sosial berupa peningkatan kelembagaan kelompok $\left(\mathrm{Y}_{2}\right)$

Tujuan dalam dimensi sosial berupa penguatan kelembagaan kelompok, dinilai berdasarkan pengakuan kelas kelompok, yang diklasifikasikan menjadi tiga tingkatan, yaitu: Kelas Pemula, Kelas Madya, dan Kelas Utama sesuai kriteria pada Pedoman Umum Penumbuhan dan Pengembangan Kelembagaan Pelaku Utama Perikanan (KKP, 2012). Data dari variabel $Y_{2}$ dikelompokkan menjadi data dikotomi, yaitu terdapat peningkatan kelembagaan kelompok dan tidak terdapat peningkatan kelembagaan kelompok. Sesuai bentuk data tersebut, maka analisis yang tepat digunakan yaitu analisis regresi logistik (Agung, 2002 dalam Baroroh, 2013) dengan sebelumnya dilakukan pengujian asumsi kebaikan model (test goodness of fit). Pengujian kebaikan model menggunakan metode Pearson Chi Square (Iriawan \& Astuti, 2006 dalam Baroroh, 2013) atas model dalam penelitian ini menunjukkan bahwa dengan tingkat keyakinan $95 \%$, dapat diyakini bahwa model regresi logistik yang digunakan dalam penelitian ini telah cukup mampu menjelaskan data/sudah memenuhi asumsi kelayakan model.

c. Terhadap tujuan dalam dimensi ekologis berupa peningkatan kualitas lingkungan $\left(\mathrm{Y}_{3}\right)$

Pengukuran variabel peningkatan kualitas lingkungan didasarkan atas jumlah sertifikasi atas penerapan Cara Budidaya Ikan Yang Baik (CBIB) oleh pembudidaya, sebagaimana diatur dalam Keputusan Menteri Kelautan dan Perikanan (KKP, 2007). Kebijakan penerapan CBIB, antara lain mencakup: (1) pembangunan tambak pada lokasi yang terhindar dari kemungkinan terjadinya pencemaran, jauh dari permukiman, industri, serta lahan pertanian dan peternakan; (2) kualitas air sumber sesuai dengan peruntukannya, tidak mengandung residu logam berat, pestisida,

Tabel 2. Nilai dan Kategori Capaian Variabel/Indeks.

Table 2. Score and Category of The Result on Variable/Index.

\begin{tabular}{lll}
$\begin{array}{c}\text { Nilai Variabel/Indeks/ } \\
\text { Scoring Variabel/Index }\end{array}$ & \multicolumn{1}{c}{$\begin{array}{c}\text { Kategori / } \\
\text { Categories }\end{array}$} & $\begin{array}{c}\text { Warna Indikator / } \\
\text { The Colours of Indicator }\end{array}$ \\
\hline $1.00-<1.40$ & Sangat Buruk / Worst & \\
$1.40-<1.80$ & Buruk / Poor & \\
$1.80-<2.20$ & Cukup / Moderate & \\
$2.20-<2.60$ & Baik / Good & \\
$2.60-3.00$ & Sangat Baik / Excellent \\
\hline
\end{tabular}


organisme patogen, cemaran dan bahan kimia lainnya; (3) saluran pasok dan saluran buang dibuat terpisah, tidak melalui daerah pemukiman, daerah industri, serta lahan pertanian dan peternakan; (4) keberadaan fasilitas MCK, toilet dan septic tank yang terletak minimal $10 \mathrm{~m}$ dari petak pemeliharaan dan saluran; (5) tidak menggunakan pupuk, probiotik, pestisida, desinfektan, dan bahan kimia yang terlarang; (6) bebas hama/patogen dan binatang peliharaan serta melakukan tindakan isolasi terhadap ikan yang terserang penyakit,dan (7) penggunaan pakan ikan tidak mengandung zat beracun, bahan pencemaran yang berbahaya bagi kesehatan ikan dan/atau manusia, atau yang mengakibatkan penurunan produksi, atau menyebabkan pencemaran/ kerusakan lingkungan.

\section{Perumusan strategiperbaikan bagipelaksanaan dan keberlanjutan program}

Berdasarkan atas hasil kesesuaian pelaksanaan dan capaian tujuan serta pengidentifikasian pengaruh variabel pelaksanaan terhadap capaian tujuan program pemberdayaan, dirumuskan strategi perbaikan bagi pelaksanaan dan keberlanjutan program pemberdayaan masyarakat pesisir.

\section{HASIL DAN PEMBAHASAN}

\section{Penilaian atas kesesuaian pelaksanaan program pemberdayaan}

Hasil penilaian, sebagaimana pada Tabel 3 menunjukkan bahwa capaian variabel pelaksanaan program pemberdayaan pada Kabupaten Karawang berada pada kisaran nilai 1,51 (kategori buruk) hingga 2,83 (kategori sangat baik).

Sebagian besar (93 responden)
pembudidaya penerima program memiliki
pengalaman budidaya yang sangat baik, yaitu
dengan lama pengalaman lebih dari empat
tahun. Hal ini dikarenakan usaha budidaya
bandeng yang mereka lakukan merupakan usaha
keluarga yang telah dilakukan secara turun
temurun. Selain itu, hal lain yang sangat baik
dalam pelaksanaan yaitu adanya kesesuaian
lokasi budidaya, yang ditunjukkan dengan kondisi
tambak dari sebagian besar pembudidaya
(93 responden) yang terhindar dari kekeringan.
Hal ini dikarenakan kecukupan sumber air payau
yang berasal dari pertemuan antara air tawar dari
hulu Sungai Citarum dan air asin dari hilir Pantai
Utara Jawa.

Tabel 3. Capaian Variabel Pelaksanaan.

Table 3. Achievement of Implementation Variables.

\begin{tabular}{|c|c|c|c|c|c|c|c|}
\hline \multirow{2}{*}{$\begin{array}{c}\text { Variabel Pelaksanaan/ } \\
\text { Implementation } \\
\text { Variable }\end{array}$} & \multicolumn{3}{|c|}{$\begin{array}{c}\Sigma \text { Responden Berdasarkan Skorl } \\
\text { Total Respondent Based on } \\
\text { Score }\end{array}$} & \multirow{2}{*}{$\begin{array}{l}\text { Total Skorl } \\
\text { Total Score }\end{array}$} & \multirow{2}{*}{$\begin{array}{l}\text { Jumlah } \\
\text { Responden/ } \\
\text { Total } \\
\text { Respondent }\end{array}$} & \multirow{2}{*}{$\begin{array}{l}\text { Capaian } \\
\text { Variabel/ } \\
\text { The Result }\end{array}$} & \multirow{2}{*}{$\begin{array}{l}\text { Kategori/ } \\
\text { Category }\end{array}$} \\
\hline & $\begin{array}{l}\text { Skor } 1 / \\
\text { Score } 1\end{array}$ & $\begin{array}{l}\text { Skor } 21 \\
\text { Score } 2\end{array}$ & $\begin{array}{l}\text { Skor } 3 / \\
\text { Score } 3\end{array}$ & & & & \\
\hline (1) & (2) & (3) & (4) & $(5)^{*}$ & (6) & $(7)^{\star *}$ & (8) \\
\hline $\begin{array}{l}\text { Lama Pengalaman } \\
\text { pembudidaya/ } \\
\text { Experience time }\end{array}$ & 2 & 15 & 93 & 311 & 110 & 2.83 & $\begin{array}{c}\text { Sangat baik } \\
\text { Excelent }\end{array}$ \\
\hline $\begin{array}{l}\text { Kejadian kekeringan/ } \\
\text { Incidence of drought } \\
\text { per year }\end{array}$ & 5 & 12 & 93 & 308 & 110 & 2.80 & $\begin{array}{c}\text { Sangat baik/ } \\
\text { Excelent }\end{array}$ \\
\hline $\begin{array}{l}\text { Aksesbilitas-jarak } \\
\text { pembelian benih/ } \\
\text { Accessibility-distance } \\
\text { to buy }\end{array}$ & 5 & 90 & 15 & 230 & 110 & 2.09 & $\begin{array}{c}\text { Cukup/ } \\
\text { Moderate }\end{array}$ \\
\hline $\begin{array}{l}\text { Ketepatan waktu } \\
\text { penyaluran/ } \\
\text { Variable aid facilities } \\
\text { delivery timeliness }\end{array}$ & 70 & 24 & 16 & 166 & 110 & 1.51 & $\begin{array}{l}\text { Buruk/ } \\
\text { Poor }\end{array}$ \\
\hline $\begin{array}{l}\text { Kecukupan jumlah } \\
\text { bantuan benih/ } \\
\text { Adequacy of the } \\
\text { amount of aid facilities }\end{array}$ & 18 & 10 & 82 & 284 & 110 & 2.58 & $\begin{array}{l}\text { Baik/ } \\
\text { Good }\end{array}$ \\
\hline $\begin{array}{l}\text { Aktivitas } \\
\text { pendampingan/ } \\
\text { Mentoring activity }\end{array}$ & 9 & 35 & 66 & 277 & 110 & 2.52 & $\begin{array}{l}\text { Baik/ } \\
\text { Good }\end{array}$ \\
\hline
\end{tabular}

Sumber: Data primer, diolah (2013) / Source: Primary data, processed (2013)

Keterangan/Notes:

* $(5)=1 \times(2)+2 \times(3)+3 \times(4)$

${ }^{* *}(7)=(5) /(6)$ 
Kecukupan jumlah bantuan juga berada dalam kategori baik. Meskipun program pemberdayaan Safver memberikan bantuan benih bandeng kepada masing-masing pembudidaya dalam jumlah yang sama tanpa memperhatikan luasan lahan dan padat tebar sebelumnya, namun jumlah benih bantuan ternyata masih melebihi dibandingkan dengan jumlah benih yang biasa ditebar pembudidaya sebelumnya. Aktivitas pendampingan oleh tenaga pendamping juga sudah memadai, yaitu 66 responden menyatakan pernah menerima aktivitas pendampingan melalui bantuan pembuatan proposal, pelatihan teknis budidaya, dan pembinaan manajemen usaha, walaupun masih terdapat 35 responden yang hanya menerima 2 kegiatan pendampingan, dan 9 responden yang hanya menerima 1 kegiatan pendampingan. Kegiatan pendampingan yang seringkali tidak direalisasikan kepada seluruh responden penerima bantuan, yaitu pemberian pelatihan teknis dan pembinaan manajemen usaha.

Variabel yang berada dalam kondisi buruk dan memerlukan upaya perbaikan, yaitu ketepatan waktu penyaluran bantuan. Sebanyak 70 responden menerima bantuan tersebut pada bulan yang tidak tepat yaitu bulan Desember, atau dua bulan setelah bulan September sampai dengan Oktober yang merupakan bulan saat pembudidaya biasa memulai musim tanam bandeng. Permasalahan ini disebabkan waktu penyaluran bantuan oleh program pemberdayaan belum memperhatikan kesesuaian musim tanam, namun lebih dipengaruhi oleh penyelesaian tahapan program, mulai dari pengusulan dan penetapan kelompok penerima bantuan hingga proses pencairan dana bantuan, yang seringkali terselesaikan pada akhir tahun.

Selanjutnya, tingkat kesesuaian pelaksanaan program ditunjukkan berdasarkan nilai Indeks Pelaksanaan Program (IPP) yang dihitung dengan rumus sebagai berikut:

IPP $=\Sigma$ capaian variabel/jumlah variabel

$\mathrm{IPP}=(2,83+2,80+2,09+1,51+2,58+2,52) / 6$ IPP $=2,39$

Berdasar perhitungan di atas, diperoleh hasil indeks sebesar 2,39 atau berada pada kisaran nilai 2,20 sampai dengan 2,60. Hal ini menunjukkan bahwa pelaksanaan program pemberdayaan masyarakat di Kabupaten Karawang memiliki tingkat kesesuaian yang baik, jika dikaitkan dengan pedoman yang ada. Variabel dengan kategori buruk, yang memerlukan upaya perbaikan guna pencapaian kategori yang lebih baik, yaitu variabel ketepatan waktu penyaluran bantuan.

\section{Penilaian atas capaian tujuan program pemberdayaan}

Hasil penilaian capaian tujuan program sebagaimana pada Tabel 5 menunjukkan bahwa seluruh variabel tujuan berada pada kategori cukup, dengan capaian terendah hingga tertinggi yaitu: variabel peningkatan kualitas lingkungan (nilai capaian 2,00), peningkatan kelembagaan kelompok (nilai capaian 2,15), dan peningkatan produksi (nilai capaian 2,18) (Tabel 4).

Dalam dimensi ekonomi, jika dibandingkan rata-rata produksi pembudidaya sebelum dan setelah pelaksanaan program, 30 responden $(27,27 \%)$ mengalami penurunan, 30 responden tetap, dan 50 responden lainnya mengalami peningkatan produksi. Penurunan total produksi antara lain disebabkan oleh ketidaktepatan waktu penyaluran bantuan, sehingga pembudidaya terpaksa menanam bandeng pada bulan dimana curah hujan sangat tinggi.

Tujuan dalam dimensi sosial berupa penguatan kelembagaan kelompok, dinilai berdasarkan pengakuan kelas kelompok. Setelah pelaksanaan program, $84,54 \%$ kelompok masih mendapat pengakuan kelas yang sama dengan sebelum pelaksanaan program, yaitu kelas pemula yang merupakan kelas terbawah dan terendah dari sisi kemampuan kelompok. Hal ini disebabkan aktivitas pendampingan yang dilakukan oleh tenaga pendamping belum mencakup kegiatan fasilitasi dinamika kelompok, baik melalui pertemuan, diskusi, dan musyawarah antar anggota kelompok.

Analisis terkait jumlah pembudidaya yang memiliki sertifikat Cara Berbudidaya Ikan yang Baik (CBIB), menunjukkan bahwa jumlah pembudidaya yang memiliki sertifikat CBIB sebelum dan sesudah pelaksanaan program pemberdayaan adalah tetap, yaitu 0 , atau sebelum dan sesudah pelaksanaan program tidak terdapat satupun pembudidaya yang memiliki sertifikat CBIB. Keengganan pembudidaya memenuhi persyaratan untuk memiliki sertifikat tersebut dikarenakan tidak adanya intensif dari pemerintah bagi pembudidaya yang memiliki sertifikat CBIB, baik berupa peningkatan harga jual bandeng, kepastian pemasaran, maupun subsidi harga pengadaan sarana produksi perikanan.

Selanjutnya, sebagai cara untuk menentukan 
Tabel 4. Capaian Masing-Masing Variabel Tujuan.

Table 4. Achievement of Each Objective's Variables.

\begin{tabular}{|c|c|c|c|c|c|c|c|}
\hline \multirow{2}{*}{$\begin{array}{l}\text { Variabel Tujuan/ } \\
\text { Goal Variables }\end{array}$} & \multicolumn{3}{|c|}{$\begin{array}{c}\Sigma \text { Responden Berdasarkan Skor I } \\
\Sigma \text { Respondent Based on Score }\end{array}$} & \multirow{2}{*}{$\begin{array}{l}\text { Total } \\
\text { Skorl } \\
\text { Total } \\
\text { Score }\end{array}$} & \multirow{2}{*}{$\begin{array}{c}\text { Jumlah } \\
\text { Responden/ } \\
\text { Total } \\
\text { Respondent }\end{array}$} & \multirow{2}{*}{$\begin{array}{c}\text { Capaian } \\
\text { Variabel/ } \\
\text { The } \\
\text { Result }\end{array}$} & \multirow{2}{*}{$\begin{array}{l}\text { Kategori/ } \\
\text { Category }\end{array}$} \\
\hline & $\begin{array}{l}\text { Skor } 1 / \\
\text { Score } 1 \\
\end{array}$ & $\begin{array}{l}\text { Skor } 21 \\
\text { Score } 2\end{array}$ & $\begin{array}{l}\text { Skor } 3 / \\
\text { Score } 3 \\
\end{array}$ & & & & \\
\hline (1) & (2) & (3) & (4) & $(5)^{*}$ & (6) & $(7)^{\star *}$ & (8) \\
\hline $\begin{array}{l}\text { Peningkatan } \\
\text { produksi/ } \\
\text { Increasing of } \\
\text { aquaculture } \\
\text { production }\end{array}$ & 30 & 30 & 50 & 240 & 110 & 2.18 & $\begin{array}{l}\text { Cukup/ } \\
\text { Moderate }\end{array}$ \\
\hline $\begin{array}{l}\text { Peningkatan } \\
\text { kelembagaan } \\
\text { kelompok/ } \\
\text { Increasing of } \\
\text { institusional } \\
\text { farmer group }\end{array}$ & 0 & 93 & 17 & 237 & 110 & 2.15 & $\begin{array}{l}\text { Cukup/ } \\
\text { Moderate }\end{array}$ \\
\hline $\begin{array}{l}\text { Peningkatan } \\
\text { kualitas } \\
\text { lingkungan/ } \\
\text { Increasing of } \\
\text { environment } \\
\text { quality }\end{array}$ & 0 & 110 & 0 & 220 & 110 & 2.00 & $\begin{array}{l}\text { Cukup/ } \\
\text { Moderate }\end{array}$ \\
\hline
\end{tabular}

Sumber: Data primer, diolah (2013) / Source: Primary data, processed (2013)

Keterangan/Notes:

* $(5)=1 \times(2)+2 \times(3)+3 \times(4)$

$* *(7)=(5) /(6)$

tingkat keberhasilan pencapaian tujuan program, dilakukan penilaian Indeks Pencapaian Tujuan (IPT) yang dihitung dengan rumus sebagai berikut:

IPT $=\Sigma$ capaian variabel / jumlah variabel

$\mathrm{IPT}=(2,18+2,15+2,00) / 3$

$\mathrm{IPT}=2,11$

Nilai Indeks Pencapaian Tujuan sebesar 2,11 menunjukkan bahwa tingkatan keberhasilan pencapaian tujuan program berada pada kategori cukup. Perbedaan capaian kategori antara Indeks Pelaksanaan Program (kategori baik) dengan Indeks Pencapaian Tujuan (kategori cukup), menunjukkan bahwa pelaksanaan program yang baik sesuai pedoman pemberdayaan belum mampu secara selaras meningkatkan capaian tujuan program pada kategori baik. Hal tersebut diduga disebabkan oleh belum seluruh intervensi kebijakan yang diperlukan untuk mewujudkan pengelolaan perikanan yang efektif diatur dalam pedoman pemberdayaan masyarakat, diantaranya yaitu: penggunaan teknologi budidaya yang sesuai, yaitu dengan pengintegrasian antara pengetahuan ekologi tradisional pembudidaya dengan penelitian sains dan pengetahuan manajemen modern (Butler et al., 2012), penyediaan fasilitas kredit mudah dengan menghubungkan pembudidaya dengan lembagalembaga institusional (Sathiadhas et al., 2014), dan kurangnya alokasi bantuan dana untuk kegiatan pengembalian kesuburan tanah (IFAD, 2001). Gambar 1 dimaksudkan untuk memperjelas pembandingan atas capaian setiap variabel pelaksanaan dan variabel tujuan (Gambar 1).

\section{Pengidentifikasian Pengaruh Variabel Pelaksanaan Terhadap Capaian Tujuan Program}

a. Terhadap tujuan dalam dimensi ekonomi berupa peningkatan produksi budidaya $\left(\mathrm{Y}_{1}\right)$

Hasil analisis regresi linear berganda sebagaimana pada Tabel 6 menunjukkan bahwa lama pengalaman pembudidaya dan aksesbilitas/ jarak pembelian benih tidak berpengaruh signifikan terhadap pencapaian tujuan peningkatan produksi, sehingga peningkatan lama pengalaman pembudidaya dan aksesbilitas pembelian benih bukan merupakan kegiatan efektif yang perlu dilakukan untuk meningkatkan produksi budidaya. Tidak berpengaruhnya variabel pengalaman 


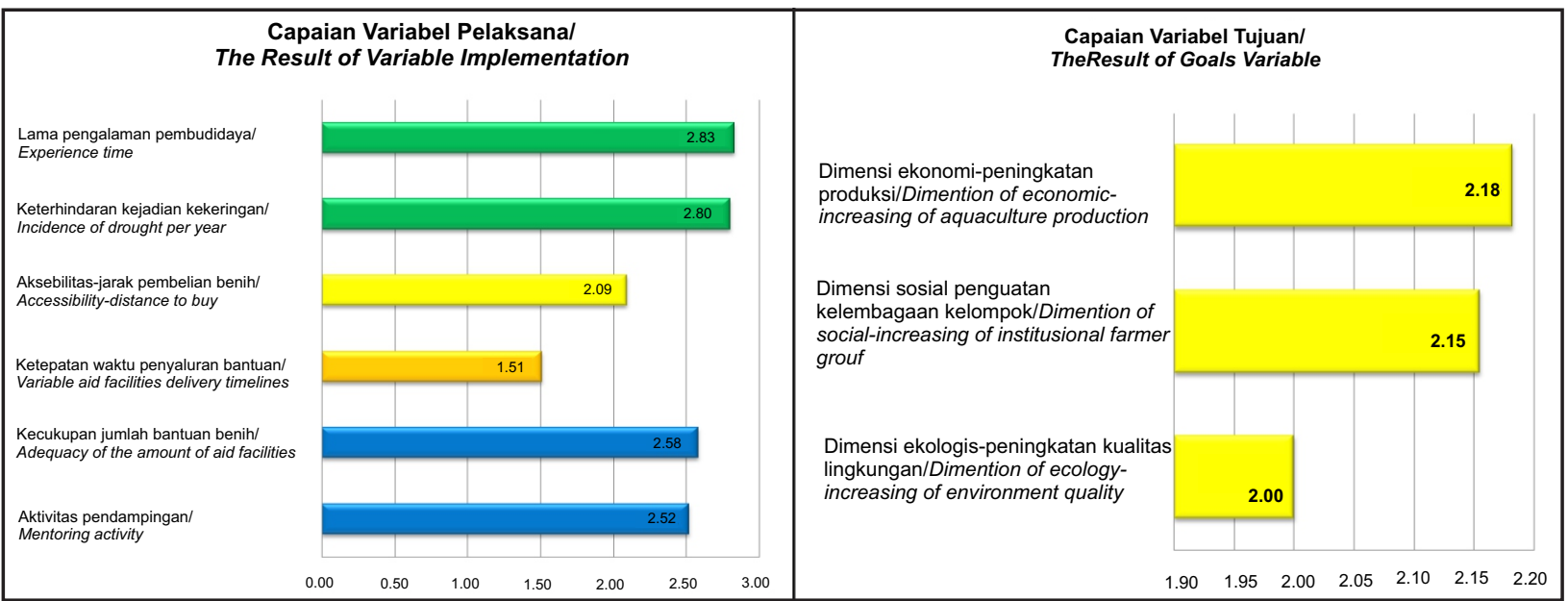

Gambar 1. Capaian Variabel Pelaksanaan dan Tujuan. Figure 1. Achievement of Implementation and Objective Variable.

pembudidaya terhadap pencapaian tujuan peningkatan produksi disebabkan teknologi budidaya bandeng secara tradisional yang dilakukan oleh pembudidaya penerima bantuan di pesisir Kabupaten Karawang merupakan teknologi sederhana yang mampu digeluti oleh masyarakat pesisir bahkan oleh pembudidaya pemula. Berdasarkan konfirmasi lebih lanjut terhadap pembudidaya bandeng yang memiliki pengalaman budidaya yang cukup lama, menunjukkan bahwa pembudidaya bandeng umumnya tidak memiliki sifat kritis terhadap faktorfaktor yang dapat menyebabkan penurunan atau peningkatan hasil produksi budidaya, sehingga lama pengalaman pembudidaya tidak secara selaras meningkatkan pengetahuan mereka tentang hal-hal yang dapat menyebabkan peningkatan produksi budidaya.

Aksesibilitas / jarak pembelian benih juga tidak berpengaruh secara signifikan karena Unit Pembenihan Rakyat (UPR) selaku produsen benih telah memahami bagaimana mengemas benih, sehingga tidak terjadi tingkat kematian benih yang tinggi disebabkan jauhnya jarak pengiriman. Selain itu, terhadap perbedaan salinitas antara hatchery tempat nener dibeli dengan tambak budidaya, pembudidaya juga telah melaksanakan proses adaptasi (aklimatisasi) terhadap benih yang dibeli dengan cara meletakkan dan mengapung-apungkan wadah benih yang berisi nener pada permukaan air tambak dan memasukkan air tambak sedikit demi sedikit, sehingga memudahkan nener beradaptasi dengan perubahan kualitas air, mencegah benih stres dan mampu mempertahankan tingkat daya tahan hidup benih.

Berdasarkan hasil analisis, variabel kejadian kekeringan mempunyai nilai signifikansi kurang dari 0,05 dan nilai $t_{\text {hitung }}$ negatif yang berarti variabel kejadian kekeringan berpengaruh negatif dan signifikan terhadap variabel tujuan peningkatan produksi. Semakin tinggi intensitas kejadian kekeringan, maka akan berpengaruh terhadap penurunan hasil produksi pembudidaya bandeng di pesisir Kabupaten Karawang. Hal yang berpengaruh positif dan signifikan terhadap pencapaian tujuan peningkatan produksi budidaya adalah ketepatan waktu penyaluran, kecukupan jumlah bantuan benih, dan aktivitas pendampingan. Semakin baik waktu penyaluran bantuan, kecukupan jumlah bantuan atau aktivitas pendampingan, maka akan berpengaruh terhadap peningkatan hasil produksi pembudidaya bandeng di pesisir Kabupaten Karawang.

Berdasarkan hasil analisis regresi linear berganda, juga diperoleh nilai koefisien determinasi (R-Square), yaitu sebesar 0,423. Hal ini menunjukkan bahwa pengaruh variabel pelaksanaan berupa: lama pengalaman pembudidaya, kejadian kekeringan, aksesbilitas/jarak pembelian benih, ketepatan waktu penyaluran, kecukupan jumlah bantuan, dan aktivitas pendampingan terhadap pencapaian tujuan dalam dimensi ekonomi berupa peningkatan produksi budidaya adalah sebesar $42,3 \%$ dan sisanya sebesar $57,73 \%$ dipengaruhi oleh variabel lain di luar model penelitian ini. 
Hasil ini menjawab permasalahan tentang adanya perbedaan capaian kategori antara Indeks Pelaksanaan Program (kategori baik) dengan Indeks Pencapaian Tujuan (kategori cukup), yang diduga disebabkan belum keseluruhan variabel pelaksanaan yang berpengaruh terhadap capaian tujuan dipersyaratkan atau diatur dalam pedoman pemberdayaan masyarakat, sehingga mengakibatkan pelaksanaan program yang baik sesuai pedoman pemberdayaan belum mampu secara selaras meningkatkan capaian tujuan program pada kategori baik. Berikut adalah model regresi yang dihasilkan dalam analisis ini adalah:

$Y_{1}=-8,909-23,374 X_{2}+17,325 X_{4}+0,356 X_{5}+$ $15,380 X_{6}$

dimana:

$\mathrm{Y}_{1}=$ Peningkatan produksi budidaya/ Increased aquaculture production

$\mathrm{X}_{2}=$ Kejadian kekeringan/ The incidence of drought

$\mathrm{X}_{4}=$ Ketepatan waktu penyaluran/ Timeliness of delivery

$\mathrm{X}_{5}=$ Kecukupan jumlah bantuan benih/ The adequacy of the amount of seed aid

$\mathrm{X}_{6}=$ Aktivitas pendampingan/ Mentoring activities

Model ini menunjukkan bahwa setiap kejadian kekeringan akan mengurangi produksi budidaya sebesar 23,374\%, ketepatan waktu penyaluran akan meningkatkan produksi budidaya sebesar $17,325 \%$, peningkatan prosentase kecukupan jumlah bantuan sebesar $1 \%$ akan meningkatkan produksi budidaya sebesar 0,356\%, dan setiap penambahan satu lingkup kegiatan pendampingan akan meningkatkan produksi budidaya sebesar $15,380 \%$.

b. Terhadap tujuan dalam dimensi sosial berupa peningkatan kelembagaan kelompok $\left(\mathrm{Y}_{2}\right)$

Berdasarkan hasil analisis regresi

Tabel 5. Hasil Analisis Regresi.

Table 5. Result of Regression Analysis.

\begin{tabular}{|c|c|c|c|c|c|}
\hline \multirow{2}{*}{$\begin{array}{l}\text { Persyaratan/ } \\
\text { Requirement }\end{array}$} & \multirow{2}{*}{\multicolumn{2}{|c|}{$\begin{array}{l}\text { Variabel/ } \\
\text { Variable }\end{array}$}} & \multicolumn{3}{|c|}{$\begin{array}{l}\text { Uji Signifikansi t (uji t)/ } \\
\text { Significant Test (t test) }\end{array}$} \\
\hline & & & $\begin{array}{l}\text { Nilai t Hitung/ } \\
t \text { Score }\end{array}$ & $\begin{array}{l}\text { Nilai Signifikansi/ } \\
\text { Significant Score }\end{array}$ & $\begin{array}{l}\text { Kesimpulan/ } \\
\text { Conclusion }\end{array}$ \\
\hline $\begin{array}{l}\text { Ketepatan penerima } \\
\text { bantuan/ } \\
\text { Exactly beneficaries }\end{array}$ & $\mathrm{X}_{1}$ & $\begin{array}{l}\text { Lama } \\
\text { Pengalaman } \\
\text { pembudidaya/ } \\
\text { Experience time }\end{array}$ & 0.793 & 0.430 & $\begin{array}{l}\text { Tidak berpengaruh/ } \\
\text { Without influence }\end{array}$ \\
\hline \multirow[t]{2}{*}{$\begin{array}{l}\text { Kesesuaian lokasi } \\
\text { Budidaya/ } \\
\text { Accuracy of location }\end{array}$} & $\mathrm{X}_{2}$ & $\begin{array}{l}\text { Kejadian } \\
\text { kekeringan/ } \\
\text { Incidence of } \\
\text { drought }\end{array}$ & -2.365 & 0.020 & $\begin{array}{l}\text { Berpengaruh negatif } \\
\text { dan signifikan/ } \\
\text { Negative influence } \\
\text { and significant result }\end{array}$ \\
\hline & $X_{3}$ & $\begin{array}{l}\text { Aksesibilitas- } \\
\text { jarak pembelian } \\
\text { benih/ } \\
\text { Accessibility- } \\
\text { distance to buy }\end{array}$ & 0.332 & 0.741 & $\begin{array}{l}\text { Tidak berpengaruh/ } \\
\text { Without influence }\end{array}$ \\
\hline \multirow[t]{2}{*}{$\begin{array}{l}\text { Ketepatan penyaluran } \\
\text { dan pemanfaatan } \\
\text { bantuan/ } \\
\text { Accuration of } \\
\text { distribution and } \\
\text { utilization of aid } \\
\text { facilities }\end{array}$} & $\mathrm{X}_{4}$ & $\begin{array}{l}\text { Ketepatan } \\
\text { waktu } \\
\text { penyaluran / } \\
\text { Variable aid } \\
\text { facilities delivery } \\
\text { timeliness } \\
\end{array}$ & 3.064 & 0.003 & $\begin{array}{l}\text { Berpengaruh positif } \\
\text { dan signifikan/ } \\
\text { Positive influence } \\
\text { and significant result }\end{array}$ \\
\hline & $X_{5}$ & $\begin{array}{l}\text { Kecukupan } \\
\text { jumlah bantuan } \\
\text { benih/ } \\
\text { Adequacy of the } \\
\text { amount of aid } \\
\text { facilities }\end{array}$ & 4.187 & 0.000 & $\begin{array}{l}\text { Berpengaruh positif } \\
\text { dan signifikan/ } \\
\text { Positive influence } \\
\text { and significant result }\end{array}$ \\
\hline $\begin{array}{l}\text { Efektivitas } \\
\text { Pendampingan/ } \\
\text { Mentoring activity }\end{array}$ & $X_{6}$ & $\begin{array}{l}\text { Aktivitas } \\
\text { pendampingan/ } \\
\text { Mentoring } \\
\text { activity }\end{array}$ & 2.416 & 0.017 & $\begin{array}{l}\text { Berpengaruh positif } \\
\text { dan signifikan/ } \\
\text { Positive influence } \\
\text { and significant result }\end{array}$ \\
\hline
\end{tabular}


logistik, sebagaimana pada Tabel 7, lima variabel pelaksanaan berupa lama pengalaman pembudidaya, kejadian kekeringan, aksesbilitas/ jarak pembelian benih, ketepatan waktu penyaluran, dan kecukupan jumlah bantuan, tidak berpengaruh terhadap capaian tujuan dalam dimensi sosial berupa peningkatan kelembagaan kelompok. Hal ini dapat dipahami karena peningkatan kelembagaan kelompok lebih banyak ditentukan oleh kesamaan pengertian dan gerak dari para pembudidaya sebagai anggota kelompok, sehingga persyaratan berupa lama pengalaman, intensitas kejadian kekeringan, jarak pembelian benih, ketepatan waktu penyaluran dan kecukupan jumlah bantuan yang diatur dalam pedoman pelaksanaan program bukanlah merupakan kebijakan yang diperlukan untuk meningkatkan kelembagaan kelompok. Dari keseluruhan variabel pelaksanaan, hanya variabel aktivitas pendampingan yang berhubungan positif dengan peningkatan kelembagaan kelompok. Nilai Odds Ratio dari variabel aktivitas pendampingan sebesar 5,584 menunjukkan bahwa peluang penambahan jenis aktivitas pendampingan terhadap peningkatan kelembagaan kelompok lebih besar 5,584 kali dibandingkan jika tidak dilakukannya penambahan jenis aktivitas pendampingan.

c. Terhadap tujuan dalam dimensi ekologis berupa peningkatan kualitas lingkungan (Y3)

Memperhatikan capaian variabel sebagaimana dinyatakan pada Tabel 5 , terlihat bahwa setelah dilakukan penilaian oleh tim penilai sertifikasi, diketahui bahwa jumlah pembudidaya di lokasi penelitian yang memiliki sertifikat CBIB sebelum dan sesudah pelaksanaan program pemberdayaan adalah tetap, yaitu 0 , atau tidak terdapat peningkatan jumlah pembudidaya yang memperoleh sertifikat CBIB. Hal ini mengandung pengertian bahwa pelaksanaan program pemberdayaan, dengan enam variabel pelaksanaan didalamnya, seluruhnya tidak berpengaruh terhadap peningkatan kualitas lingkungan. Hasil ini mengandung pengertian bahwa program pemberdayaan dengan persyaratan dan pelaksanaan yang ada saat ini belum menyentuh kepentingan peningkatan kualitas lingkungan, atau terjadi ketimpangan dalam pencapain tujuan dalam dimensi ekologis. Hal ini tentunya tidak sejalan dengan konsep pengelolaan berkelanjutan, yang menyebutkan bahwa aspek berkelanjutan harus meliputi aspek ekologis, ekonomi, dan sosial secara bersamaan. Mengatasi permasalahan ini diperlukan perubahan lingkup pelaksanaan kegiatan pemberdayaan atau bahkan program/ kegiatan baru untuk mendukung pencapaian tujuan peningkatan kualitas lingkungan.

\section{Perumusan Strategi Perbaikan Bagi Pelaksanaan dan Keberlanjutan Program}

Untuk dapat memberikan manfaat dalam meningkatkan kesejahteraan pembudidaya di wilayah pesisir, dirumuskan strategi perbaikan bagi pelaksanaan dan keberlanjutan program pemberdayaan masyarakat pesisir berdasarkan atas kelemahan-kelemahan yang ditemui pada pembahasan. Beberapa hal perlu dilakukan oleh pemerintah untuk mendorong capaian tujuan program pemberdayaan masyarakat pesisir berbasis pengelolaan berkelanjutan. Dalam penelitian ini, setidaknya terdapat tiga opsi kebijakan yang perlu

Tabel 7. Hasil Analisis Regresi Logistik.

Table 7. Result of Logistic Regression Analysis.

\begin{tabular}{|c|c|c|c|c|c|c|c|}
\hline \multicolumn{8}{|c|}{ Variabel dalam Persamaan / Variables in The Equation } \\
\hline & & B & S.E. & Wald & Df & Sig. & $\operatorname{Exp}(B)$ \\
\hline \multirow{7}{*}{ Step $1^{a}$} & $\mathrm{X} 1$ & -.026 & .048 & .296 & 1 & .586 & .974 \\
\hline & $\mathrm{X} 2$ & $-18,472$ & 7709,496 & .000 & 1 & .998 & .000 \\
\hline & X3 & -.012 & .039 & .092 & 1 & .761 & .988 \\
\hline & $\mathrm{X} 4$ & .491 & .377 & 1,692 & 1 & .193 & 1,633 \\
\hline & $\times 5$ & .003 & .006 & .324 & 1 & .569 & 1,003 \\
\hline & $\mathrm{X} 6$ & 1,720 & .759 & 5,136 & 1 & .023 & 5,584 \\
\hline & Constant & $-7,000$ & 2,506 & 7,799 & 1 & .005 & .001 \\
\hline
\end{tabular}

a. Variable(s) entered on step 1: X1, X2, X3, X4, X5, X6.

Sumber: Data primer diolah dengan SPSS/ Source: Primary data processed with SPSS 
dilakukan, yaitu: (1) penyesuaian waktu penyaluran bantuan dengan musim tanam untuk meningkatkan efektifitas capaian tujuan dalam dimensi ekonomi, berupa peningkatan produksi; (2) peningkatan dukungan terhadap aktivitas pendampingan oleh tenaga penyuluh, untuk meningkatkan capaian tujuan dalam dimensi sosial, berupa peningkatan kelembagaan kelompok, dan (3) peningkatkan capaian tujuan dalam dimensi ekologis melalui pemberian intensif bagi pembudidaya yang memiliki sertifikat CBIB.

\section{a. Penyesuaian Waktu Penyaluran Bantuan Dengan Musim Tanam}

Berdasarkan penilaian atas kesesuaian pelaksanaan program pemberdayaan sebagaimana terdapat pada bahasan sebelumnya, variabel ketepatan waktu penyaluran bantuan teridentifikasi di lapangan sebagai variabel yang memperoleh kategori paling buruk. Hal ini membawa implikasi perlunya upaya perbaikan guna pencapaian kategori yang lebih baik atas variabel ketepatan waktu penyaluran. Terlebih jika melihat hasil pengidentifikasian pengaruh variabel pelaksanaan terhadap capaian tujuan dalam dimensi ekonomi, ternyata variabel ketepatan waktu penyaluran bantuan berpengaruh positif dan signifikan terhadap pencapaian tujuan peningkatan produksi, sehingga ketepatan waktu penyaluran bantuan merupakan hal efektif yang perlu dilakukan untuk meningkatkan produksi budidaya.

Sebagaimana dinyatakan pada Tabel 4, 94 pembudidaya yang berada di lokasi penelitian menerima bantuan tidak sesuai musim tanam, yaitu diantaranya menerima bantuan pada bulan Desember yang merupakan bulan dengan curah hujan yang sangat tinggi, yaitu pada Kecamatan Tirtajaya sebesar $110 \mathrm{~mm}^{3}$, dari rata-rata curah hujan / bulan sebesar 38,33 mm³ $^{3}$ (BPS Kabupaten Karawang, 2012ª), dan pada Kecamatan Cilamaya Wetan sebesar $25 \mathrm{~mm}^{3}$ dari rata-rata curah hujan sebesar 20,75 $\mathrm{mm}^{3}$ (BPS Kabupaten Karawang, $2012^{b}$ ). Terkait hal tersebut, Rusmiyati (2012) dalam publikasinya menyatakan bahwa pada musim hujan, klekap sebagai makanan utama bagi bandeng tumbuh tidak sebanyak pada musim kemarau, dan cenderung mudah lepas dari tanah dasar petakan, mengapung, dan mengelompok di sisi petakan akibat dihembus oleh angin sehingga tidak dapat dimanfaatkan oleh ikan bandeng yang dipelihara. Penurunan kadar garam (salinitas) akibat curah hujan yang terlalu tinggi juga menghalangi pertumbuhan klekap, dan dapat menyebabkan kerusakan dari klekap bila terjadi perubahan yang mendadak terhadap salinitas air.

Memperhatikan hal ini, perbaikan kebijakan perlu dilakukan dengan menyalurkan bantuan sesuai musim tanam. Proses pengusulan dan penetapan kelompok penerima bantuan yang selama ini memerlukan waktu beberapa bulan, dapat dilakukan pada tahun sebelumnya, sehingga pada tahun berjalan, proses pencairan bantuan dapat segera dilakukan dengan sesuai musim tanam.

\section{b. Peningkatan Dukungan terhadap Aktivitas Pendampingan oleh Tenaga Penyuluh}

Berdasarkan hasil pengidentifikasian pengaruh variabel pelaksanaan terhadap capaian tujuan dalam dimensi sosial, ternyata dari enam variabel pelaksanaan, hanya variabel aktivitas pendampingan yang memengaruhi peningkatan kelembagaan kelompok. Sementara di sisi lain, hasil penilaian atas capaian tujuan program, menunjukkan bahwa variabel capaian tujuan program dalam dimensi sosial, berupa peningkatan kelembagaan kelompok masih berada pada kategori cukup, yang tentu saja perlu ditingkatkan untuk pencapaian kategori yang lebih baik.

Untuk itu, perlu dilakukan revitalisasi kegiatan pendampingan dengan penambahan kegiatan berupa fasilitasi dinamika kelompok melalui pertemuan, diskusi, dan musyawarah antar anggota kelompok, sehingga tercipta kesamaan gerak dan pikiran dari pembudidaya sebagai anggota kelompok. Pertemuan rutin bulanan untuk membentuk kelompok-kelompok yang kuat perlu dilakukan, sehingga permasalahan-permasalahan yang ada di tambak, seperti halnya penanganan dan pemberantasan hama, pembagian air melalui saluran, dan pengaturan jadwal panen untuk menghindari turunnya harga jual dapat bersamasama mereka atasi.

Hingga saat ini, belum terdapat pendampingan berkelanjutan atas usaha budidaya yang dilakukan oleh penerima bantuan. Tenaga pendamping, baik Penyuluh Perikanan Tenaga Kontrak (PPTK) maupun Penyuluh Perikanan Berbasis Masyarakat (PPBM) melaksanakan pendampingan terhadap kelompok penerima bantuan hanya sebatas pada tahun berjalan. Pada tahun berikutnya, perhatian tenaga penyuluh sudah tercurah pada proses pengusulan dan penetapan anggota kelompok, sehingga proses pendampingan terhadap usaha budidaya yang 
dilakukan oleh penerima bantuan tidak lagi dilakukan. Hanafi et al. (2011) menyebutkan bahwa saat ini komposisi jumlah penyuluh perikanan dan jumlah petambak yang ada sangat tidak berimbang, sehingga proses alih ketrampilan dan teknologi budidaya ikan tidak maksimal dilakukan. Pengawasan dan bimbingan langsung kepada petambak sulit dilakukan, sehingga hanya sebagian kecil kelompok yang dapat dikunjungi oleh penyuluh perikanan. Penambahan jumlah tenaga penyuluhan perikanan melalui perekrutan tenaga penyuluh yang berasal dari masyarakat lokal atau kontrak kerja dengan Sekolah Tinggi Perikanan dengan model magang mahasiswa perikanan dapat menjadi solusi efektif dalam mengatasi permasalahan ini. Perbaikan kebijakan perlu dilakukan KKP dengan memberikan dukungan terhadap kegiatan penyuluhan, baik berupa pemenuhan tenaga penyuluhan maupun operasionalisasi fasilitasi dinamika kelompok.

\section{c. Pemberian Insentif Bagi Pembudidaya yang Memiliki Sertifikat CBIB}

Hasil penilaian sebagaimana pada Tabel 5 menunjukkan bahwa jumlah pembudidaya yang memiliki sertifikat CBIB sebelum dan sesudah pelaksanaan program pemberdayaan adalah tetap, yaitu 0 , atau sebelum dan sesudah pelaksanaan program tidak terdapat satupun pembudidaya yang memiliki sertifikat CBIB. Keengganan pembudidaya memenuhi persyaratan untuk memiliki sertifikat tersebut dikarenakan tidak adanya intensif dari pemerintah bagi pembudidaya yang memiliki sertifikat CBIB, baik berupa peningkatan harga jual bandeng, kepastian pemasaran, maupun subsidi harga pengadaan sarana produksi perikanan. Untuk itu, pemerintah melalui KKP perlu mengusahakan terciptanya insentif bagi pembudidaya yang memiliki sertifikat $\mathrm{CBIB}$, sehingga peningkatan kualitas lingkungan untuk mendukung budidaya yang berkelanjutan dapat direalisasikan.

\section{KESIMPULAN DAN IMPLIKASI KEBIJAKAN}

\section{Kesimpulan}

1. Indeks Pelaksanaan Program yang menyatakan tingkat kesesuaian pelaksanaan program pemberdayaan masyarakat pesisir adalah sebesar 2,39 dengan kategori baik. Indikator pelaksanaan yang memerlukan upaya perbaikan guna pencapaian kategori yang lebih baik, yaitu indikator ketepatan waktu penyaluran bantuan.

2. Indeks Pencapaian Tujuan yang menyatakan tingkat capaian tujuan program pemberdayaan adalah sebesar 2,11 dengan kategori cukup. Seluruh indikator capaian tujuan yang meliputi peningkatan produksi, peningkatan kelembagaan (kelas) kelompok, dan peningkatan kualitas lingkungan berada pada kategori cukup dan memerlukan perhatian dan upaya perbaikan guna pencapaian kategori yang lebih baik.

3. Terhadap pencapaian tujuan dalam dimensi ekonomi berupa peningkatan produksi budidaya, variabel ketepatan waktu penyaluran, kecukupan jumlah bantuan, dan aktivitas pendampingan berpengaruh positif, sedangkan variabel kejadian kekeringan berpengaruh negatif.

4. Untuk pencapaian tujuan dalam dimensi sosial, hanya variabel aktivitas pendampingan yang berpengaruh signifikan terhadap peningkatan kelembagaan (kelas) kelompok.

5. Keseluruhan variabel pelaksanaan tidak berpengaruh terhadap capaian tujuan dalam dimensi ekologis berupa peningkatan kualitas lingkungan.

\section{Implikasi Kebijakan}

1. Dengan memperhatikan hasil analisis, beberapa opsi kebijakan yang perlu dilakukan oleh KKP yaitu berupa: 1) Peningkatan capaian tujuan program pemberdayaan dalam dimensi ekonomi, melalui penyesuaian waktu penyaluran bantuan dengan musim tanam, 2) Peningkatan capaian tujuan dalam dimensi sosial melalui dukungan terhadap aktivitas pendampingan oleh tenaga penyuluh, dan 3) Peningkatkan capaian tujuan dalam dimensi ekologis melalui pemberian intensif bagi pembudidaya yang memiliki sertifikat CBIB.

2. Untuk lebih dapat meningkatkan capaian tujuan program pemberdayaan, perlu dilakukan kajian atas pengaruh variabel lain yang diduga diperlukan untuk mewujudkan pengelolaan perikanan yang efektif, selain yang diatur dalam pedoman pemberdayaan, diantaranya yaitu: penggunaan teknologi budidaya yang sesuai, yaitu dengan pengintegrasian antara pengetahuan ekologi tradisional pembudidaya dengan penelitian sains dan pengetahuan manajemen modern, penyediaan fasilitas 
kredit mudah dengan menghubungkan pembudidaya dengan lembaga-lembaga institusional, ataupun peningkatan alokasi bantuan dana untuk kegiatan pengembalian kesuburan tanah.

\section{DAFTAR PUSTAKA}

Agung, I.G.N. 2002. Statistika: Aplikasi Hubungan Kausal Berdasarkan Data Kategorik. In Baroroh, A. 2013. Analisis Multivariat dan Time Series dengan SPSS 21. Elex Media Komputindo. Jakarta. 220 hal.

Baroroh, A. 2013. Analisis Multivariat dan Time Series dengan SPSS 21. Jakarta: Elex Media Komputindo.

BPS Kabupaten Karawang. 2012 a . Statistik Daerah Kecamatan Tirtajaya Tahun 2012. BPS Kabupaten Karawang. Karawang. 72 hal.

BPS Kabupaten Karawang. 2012 . Kecamatan Cilamaya Wetan dalam Angka 2012. BPS Kabupaten Karawang. Karawang. 72 hal.

Direktorat Jenderal Perikanan Budidaya. 2009. Pedoman Pemberian Input Produksi kepada Pembudidaya Ikan Penerima Manfaat Proyek Safver. Satker Pengembangan Akuakultur untuk Ketahanan Pangan dan Pengurangan Kemiskinan Proyek Safver Direktorat Jenderal Perikanan Budidaya. Jakarta. 52 hal.

Direktorat Jenderal Perikanan Budidaya. 2012. Keputusan Direktur Jenderal Perikanan Budidaya Nomor: KEP.45/DJ-PB/2012 tentang Pedoman Teknis Pengembangan Usaha Mina Pedesaan Perikanan Budidaya. Direktorat Jenderal Perikanan Budidaya. Jakarta. 79 hal.

Hanafi, A., A.I. Supii, W. Adriyanto, A.B. Prasetio \& A. Sudradjat. 2011. Kebijakan Strategis Pengembangan Bisnis Budidaya Bandeng. Analisis Kebijakan Pembangunan Perikanan Budidaya:137-151.
Karim, M. 2005. Analisis Kemiskinan dan Kesenjangan Pembangunan di Kawasan Pesisir Kabupaten Karawang dan Sukabumi Jawa Barat. Tesis. Departemen Manajemen Sumberdaya Perairan, Sekolah Pasca Sarjana, Institut Pertanian Bogor. Bogor. 228 hal.

KKP (Kementerian Kelautan dan Perikanan). 2007. Keputusan Menteri Kelautan dan Perikanan Republik Indonesia Nomor KEP.02/MEN/2007 tentang Cara Budidaya Ikan yang Baik. Kementerian Kelautan dan Perikanan. Jakarta. 11 hal.

KKP (Kementerian Kelautan dan Perikanan). 2012. Keputusan Menteri Kelautan dan Perikanan Republik Indonesia Nomor KEP.14/MEN/2012 tentang Pedoman Umum Penumbuhan dan Pengembangan Kelembagaan Pelaku Utama Perikanan. Kementerian Kelautan dan Perikanan. Jakarta. 33 hal.

Latan \& Temalagi. 2013. Analisis Multivariate Teknik dan Aplikasi Menggunakan Program IBM SPSS 20.0. Penerbit Alfabeta. Bandung. 152 hal.

Mulyanto. 2012. Analisis Faktor Penyebab dan Karakteristik Model Pengentasan Kemiskinan di Kota Surakarta. Jurnal Sosial Ekonomi STIE AUB Surakarta: 87 - 102.

Rusmiyati, S. 2012. Budidaya Bandeng Super, Langkah Jitu Menuju Kemapanan Finansial. Pustaka Baru Press. Yogyakarta. 205 hal.

Suriadarma. 2011. Dampak Beberapa Parameter Faktor Fisika Kimia Terhadap Kualitas Lingkungan Perairan Wilayah Pesisir Karawang-Jawa Barat. Jurnal Riset Geologi dan Pertambangan, Vol 21: 19-33.

Qtt, W.R. 1978. Environmental Indices, Theory and Practice, An Arbor Science. Publ Inc Ann. Arbor Mich. 


\section{Lampiran / Appendix}

Lampiran 1. Anggota Kelompok Penerima Bantuan dan Responden Kueisoner. Appendix 1. The Member of The Group Beneficiary and Responden's Study.

\begin{tabular}{|c|c|c|c|c|c|}
\hline $\begin{array}{l}\text { Program/ } \\
\text { Program }\end{array}$ & $\begin{array}{c}\text { Lokasi } \\
\text { Penelitian } \\
\text { (Kecamatan) I } \\
\text { Study Location } \\
\text { (District) }\end{array}$ & $\begin{array}{c}\Sigma \text { Kelompok } \\
\text { Penerima Bantuan / } \\
\text { Total Amount of } \\
\text { Group Beneficiary }\end{array}$ & $\begin{array}{l}\text { Nama Kelompok/ } \\
\text { The Name of The } \\
\text { Group Beneficiary }\end{array}$ & $\begin{array}{c}\Sigma \text { anggota klpk/ } \\
\text { Total Amount } \\
\text { of The Member }\end{array}$ & $\begin{array}{l}\text { Responden/ } \\
\text { Respondent }\end{array}$ \\
\hline \multirow{4}{*}{$\begin{array}{l}\text { PUMP-PB } \\
\text { TA } 2012\end{array}$} & Tirtajaya & 2 & 1. Mina Sari & 10 & 8 \\
\hline & & & $\begin{array}{ll}\text { 2. Tambak } \\
\text { Sejahtera }\end{array}$ & 10 & 10 \\
\hline & Cilamaya Wetan & 1 & $\begin{array}{l}\text { 1. Samudera } \\
\text { Timbul Jaya }\end{array}$ & 10 & 10 \\
\hline & & & Sub total 1 & 30 & 28 \\
\hline \multirow{7}{*}{$\begin{array}{l}\text { Safver } \\
\text { TA } 2011\end{array}$} & Tirtajaya & 6 & 1. Wana Sari 1 & 25 & 2 \\
\hline & & & 2. Wana Sari 2 & 19 & 1 \\
\hline & & & 3. Wana Jaya 1 & 13 & 1 \\
\hline & & & 4. Wana Lestari 1 & 19 & 5 \\
\hline & & & 5. Wana Lestari 2 & 22 & 5 \\
\hline & & & 6. Wana Lestari 3 & 15 & 3 \\
\hline & & & Sub total 2 & 113 & 17 \\
\hline \multirow{12}{*}{$\begin{array}{l}\text { Safver } \\
\text { TA } 2012\end{array}$} & Tirtajaya & 10 & 1. Mina Lestari & 18 & 1 \\
\hline & & & 2. Mina Warsa & 8 & 1 \\
\hline & & & 3. Minahasa Jaya & 4 & 0 \\
\hline & & & 4. Minajaya Subur & 9 & 5 \\
\hline & & & 5. Windu mandiri & 15 & 9 \\
\hline & & & 6. Windu jaya & 23 & 5 \\
\hline & & & 7. Nener jaya & 22 & 8 \\
\hline & & & 8. Nener mandiri & 20 & 3 \\
\hline & & & 9. Mina Tirta & 24 & 15 \\
\hline & & & 10. Mina Bakti & 27 & 18 \\
\hline & & & Sub total 3 & 170 & 65 \\
\hline & & & Total & 313 & 110 \\
\hline
\end{tabular}

Lampiran 2. Perhitungan Jumlah Sampel Mengacu Pada Rumus Slovin

Appendix 2. Calculation of The Sample Size Refers to The Slovin Formula

$\mathrm{n}=\mathrm{N} / 1+(\mathrm{Ne} 2)$

$\mathrm{n}=313 / 1+(313 \times 0,12)$

$\mathrm{n}=75,79$ dibulatkan / Accomplished 76

dimana:

$\mathrm{n}$ = Jumlah sampel yang dicari / The number of samples sought

$\mathrm{N}$ = Jumlah populasi / The number of population

$\mathrm{e}=$ Tingkat kesalahan dalam pengambilan sampel / The level of error in sampling $(=0,1)$ 